\title{
THE ELKIN PAPERS: A BRIEF DESCRIPTION AND GUIDE TO THE COLLECTION
}

\author{
Jennifer Laycock
}

When Emeritus Professor A.P. Elkin, C.M.G., died in July 1979 he was still editor of Oceania Publications and still actively involved in academic affairs. His career and achievements have been well described elsewhere. Some introduction is useful, however, as a context for the brief description of his papers which follows. The collection amounts to some two hundred archive boxes, together with a quantity of 'loose' material such as films, records, tape-recordings and maps. It covers the years 1891-1979, with most of the material falling into the period between 1926, when the Anthropology Department of the University of Sydney was founded and 1956, when Professor Elkin retired.

A.P. Elkin held the chair of Anthropology at the University of Sydney for twenty-three years, and prior to this appointment had been associated with the Department as research worker and lecturer. He belonged to many organisations and made significant contributions in many fields. He was, for example, a member of the New South Wales Aborigines Welfare Board from 1939 and its vice-chairman for twenty-six years. He also played an important part in shaping Aboriginal policy implemented by the Commonwealth and other States, and the collection includes correspondence with various State and Commonwealth politicians and officials from the late 1920s. Elkin also corresponded with numerous Aboriginal organisations throughout Australia He collected newspaper clippings on Aborigines from the 1920 s.

The collection contains much valuable material for the study of Aboriginal history. One rare document included is the Manual of instructions to managers and matrons of Aboriginal stations and other field officers issued by the New South Wales Aborigines Welfare Board. Moreover, there are a number of agenda documents for Board meetings in the 1960s. Such agenda papers, which appear to be more detailed than the minutes of meetings, have not survived as a complete set among records held elsewhere. Two other items worth mentioning are a collection of correspondence, reports and other documents on the Guided Projectiles Project in central Australia in 1947, and correspondence and reports concerning the survey of Aboriginal labour and conditions on Northern Territory pastoral properties conducted by R.M. and C.H. Berndt in 1945-46 for the Australian Investment Agency (Vesteys).

Professor Elkin's papers include not only his own research notes, correspondence, teaching material and writings in anthropology, sociology and history, but also records of the origin and development of academic anthropology in Australia. All correspondence of Sydney University's Department of Anthropology from its foundation in 1926 until Elkin's retirement in 1956 (except for the period 1939-43) is included in the collection, together with papers of the Australian National Research Council from 1926. The Elkin Papers also include records of the journals Oceania (from 1930), Archaeology and Physical Anthropology in Oceania, and Human Biology in Oceania until Elkin's death in 1979.

The largest part of the collection is made up of written material, but there are about eighteen boxes of audio-visual material including prints, negatives, slides, tapes, records and films. Manuscript material includes such things as field notes, notes on Professor Elkin's reading and research, and notes for lectures, addresses, articles and correspondence. Published material includes newspaper clippings, pamphlets and leaflets, publications, reports, etc.

The Elkin Papers are being catalogued in the Department of Anthropology at the University of Sydney and will eventually be deposited in the University of Sydney Archives. Arrangements for access have not been finally decided. For the time being researchers wishing to see any part of the collection should seek permission from Professor P.K. Elkin (English Department, University of New England, Armidale N.S.W.), and Professor Peter Lawrence (Anthropology Department, University of Sydney). For some papers in the Elkin 
collection not written by Professor Elkin himself, permission of the author(s) is required before access can be granted.

Appendix 1 is intended to indicate the range of contents of the papers as well as their arrangement. Further details are available on request from the Department of Anthropology, University of Sydney.

UNIVERSITY OF SYDNEY

\title{
APPENDIX I
}

THE ELKIN PAPERS: A SHORT GUIDE TO THE COLLECTION

A. RESEARCH MATERIAL

\author{
1. AUSTRALIA (BY AREA) \\ Kimberleys \\ H.J. Coate \\ South Australia \\ New South Wales \\ Queensland \\ Northern Territory \\ W.E. Harney \\ O.M. Pink \\ R.H. Mathews
}

2. AUSTRALIA (BY SUBJECT)

Human biology

Prehistory

Economics and material culture

Social organisation

Religion and magic

Music

Art

Linguistics

3. NEW GUINEA AND THE PACIFIC

4. ABORIGINAL-WHITE CONTACT AND HISTORY

Government policy and administration (by state)

Missions (by denomination)

Aboriginal organisations (alphabetical)

Organisations (miscellaneous)

Elkin's working notes

(Main headings: Writings on Aborigines since 1788; Contact, policy and administration; Surveys, statistics, etc; Aborigines and the law; Education; Culture contact comparative material; Culture)

Addresses and lectures by Elkin

Guided Projectiles Project

Articles by authors other than Elkin

5. SOCIOLOGICAL RESEARCH

6. RESEARCH DATA FILES

B. ORGANISATIONS AND COMMITTEES, ETC

1. ANTHROPOLOGICAL

Anthropology Society of New South Wales

ANZAAS

South Pacific Commission 
Pacific Science Association

Pan Indian Ocean Science Association

Australian Museum

Australian Institute of Aboriginal Studies

Institute for Aboriginal Development

Australian Association of Social Anthropologists

Academy of the Social Sciences in Australia

2. UNIVERSITY OF SYDNEY

St Paul's Coliege

International House

Selle House

Senate/Finance Committee

3. NEW SOUTH WALES GOVERNMENT

Road Safecy Council

Geographical Names Board

4. OTHER

Australian-India Association

C. HISTORY OF ANTHROPOLOGY IN AUSTRALIA

I. Australian National Research Council

2. Oceania Publications

3. Correspondence

Anthropology Deparment 1926-1956

Personal 1956-1979

D. PERSONAL AND BIOGRAPHICAL 